Review

\title{
Experimental Animal Models of Pancreatic Carcinogenesis for Prevention Studies and Their Relevance to Human Disease
}

\author{
Mami Takahashi ${ }^{1, *}$, Mika Hori ${ }^{1}$, Michihiro Mutoh ${ }^{1}$, Keiji Wakabayashi ${ }^{2}$ and \\ Hitoshi Nakagama ${ }^{1}$
}

1 Division of Cancer Development System, Carcinogenesis Research Group, National Cancer Center Research Institute, 1-1, Tsukiji 5-chome, Chuo-ku, Tokyo 104-0045, Japan;

E-Mails: mihori@ncc.go.jp (M.H.); mimutoh@ncc.go.jp (M.M.); hnakagam@ncc.go.jp (H.N.)

2 Graduate School of Nutritional and Environmental Sciences, University of Shizuoka, Yada 52-1, Suruga-ku, Shizuoka 422-8526, Japan; E-Mail: gp1576@u-shizuoka-ken.ac.jp

* Author to whom correspondence should be addressed; E-Mails: mtakahas@ncc.go.jp; Tel.: +81-3-3542-2511; Fax: +81-3-3543-9305.

Received: 1 December 2010; in revised form: 29 December 2010 / Accepted: 26 January 2011 / Published: 9 February 2011

\begin{abstract}
Pancreatic cancer is difficult to cure, so its prevention is very important. For this purpose, animal model studies are necessary to develop effective methods. Injection of $\mathrm{N}$-nitrosobis(2-oxopropyl)amine (BOP) into Syrian golden hamsters is known to induce pancreatic ductal adenocarcinomas, the histology of which is similar to human tumors. Moreover, K-ras activation by point mutations and p16 inactivation by aberrant methylation of 5' CpG islands or by homozygous deletions have been frequently observed in common in both the hamster and humans. Thus, this chemical carcinogenesis model has an advantage of histopathological and genetic similarity to human pancreatic cancer, and it is useful to study promotive and suppressive factors. Syrian golden hamsters are in a hyperlipidemic state even under normal dietary conditions, and a ligand of peroxizome proliferator-activated receptor gamma was found to improve the hyperlipidemia and suppress pancreatic carcinogenesis. Chronic inflammation is a known important risk factor, and selective inhibitors of inducible nitric oxide synthase and cyclooxygenase- 2 also have protective effects against pancreatic cancer development. Anti-inflammatory and antihyperlipidemic agents can thus be considered candidate chemopreventive agents deserving more attention.
\end{abstract}


Keywords: pancreatic cancer; hyperlipidemia; iNOS; hamster; BOP

\section{Introduction}

In recent years, pancreatic cancer has increased to become the fifth leading cause of cancer mortality in Japan [1]. Since the five-year-survival rate is very low, elucidation of the mechanisms of pancreatic carcinogenesis and development of prevention methods are important high priority tasks. Factors affecting pancreatic cancer development have been studied using several in vivo animal models [2]. Use of $N$-nitrosobis(2-oxopropyl)amine (BOP) in the Syrian golden hamster is known to be unique for development of pancreatic ductal adenocarcinomas, the histology of which is similar to that in human cases [3-6]. In the hamster model, early lesions such as focal hypertrophy, hyperplasia, goblet cell metaplasia, atypical hyperplasia and in situ carcinoma sequentially develop in the common duct, pancreatic duct and ductules, but not in acinar cells [7]. Transplacental induction of pancreatic ductal cancer by 4-(methylnitrosamino)-1-(3-pyridyl)-1-butanone (NNK) and ethanol in Syrian golden hamster is also an interesting model to investigate a synergistic effect of cigarette smoking and alcohol drinking on fetuses [8]. In rats, the azaserine-induced pancreatic cancer model is well-known, but the lesions are acinar cell carcinomas [9]. A nitrosourea amino acid carcinogen, $N$-delta-( $N$-methyl- $N$-nitrosocarbamoyl)-L-ornithine (MNCO), has further been shown to cause pancreatic acinar cell carcinomas in rats [10] and ductal carcinomas in hamsters [11]. Different from in hamsters, BOP mainly induces thyroid gland tumors in rats $[12,13]$ and lung and liver tumors in mice [14]. There is thus a species specificity in the types of pancreatic neoplasm induced in rodents [15-17]. The 7,12-dimethylbenzanthracene (DMBA)-induced pancreatic cancer model can also be employed as a chemical carcinogenesis model in rats [18,19] and mice [20]. In this case, direct implantation of the carcinogen into the head of the pancreas causes tubular complexes in acini and induces pancreatic neoplasms of ductal phenotype in which cytokeratin 19 is expressed [21] and K-ras gene mutations are present [22]. Recently, genetically engineered mouse (GEM) models of pancreatic exocrine cancer have been developed and used to elucidate mechanisms of pancreatic carcinogenesis, although the pathology is somewhat different from human cases [23]. Mouse models with pancreas-specific expression of mutant K-ras from the embryonic stage frequently develop acinar-to-ductal metaplasia and pancreatic intraductal neoplasms (PanINs), but few pancreatic cancers under normal conditions [24-26]. Additional alterations in tumor-suppressor genes, such as p16 [27], p53 [28], $d p c 4$ [29], and TGF- $\beta$ receptor II [30], or pancreatitis [31] in the GEM models have been shown to cause quite high incidences of pancreatic cancers. On the other hand, conditional expression of mutant K-ras in the adult phase hardly induces PanINs and cancer if without pancreatitis [31]. Transgenic rats that express a mutated Ha- or K-ras oncogene regulated by the Cre/lox system have also been demonstrated to develop pancreatic ductal carcinomas upon injection of a Cre-carrying adenovirus into the pancreatic ducts and acini via the common bile duct $[32,33]$. In these rat models, mutant Ras is conditionally expressed in the pancreas of young adult rats and neoplastic lesions arise in pancreatic duct epithelium, intercalated ducts and centroacinar cells, but not acinar cells [32]. 
Here, we focus on the BOP-induced pancreatic cancer model in hamsters and discuss its utility for cancer prevention studies.

\section{Genetic Alterations in Pancreatic Ductal Carcinomas of Humans and BOP-treated Hamsters}

Pancreatic carcinogenesis is known to be a multi-step process involving multiple genetic alterations in humans [34-37] and similar genetic alterations have been found in hamsters [38,39]. Findings for genetic alterations in pancreatic ductal cancers in the two species are summarized in Table 1.

Table 1. Gene alterations in pancreatic cancers in humans and hamsters [34-60].

\begin{tabular}{|c|c|c|c|}
\hline \multirow[b]{2}{*}{ Gene } & \multirow[b]{2}{*}{ Alterations } & \multicolumn{2}{|c|}{ Frequency in (\%) } \\
\hline & & Human & $\begin{array}{l}\text { Hamster } \\
\text { (BOP-treated) }\end{array}$ \\
\hline K-ras & Mutation & $75-100$ & $70-95$ \\
\hline$p 16^{I N K 4 A} / C D K N 2 A$ & CpG methylation/Deletion/Mutation & 80-95 & 93 \\
\hline DPC4/SMAD4 & Deletion / Mutation + LOH & 50 & 8 \\
\hline$D C C$ & Deletion & 50 & 53 \\
\hline P53 & Mutation + LOH & $40-75$ & 0 \\
\hline FHIT & Aberrant transcripts & 62 & 73 \\
\hline
\end{tabular}

LOH: loss of heterozygosity

K-ras is quite frequently mutated in pancreatic ductal carcinomas in hamsters (70-95\%) [40-42] as well as humans (75-100\%) [43-45], resulting in activation of downstream signaling proteins such as elements in the Raf/MEK/MAPK and PI3K/Akt pathways. K-ras mutations are also observed in early lesions, such as atypical ductal hyperplasia in hamsters and humans [41,46]. The major K-ras mutation in BOP-induced pancreatic carcinomas in hamsters is predominantly a $\mathrm{G}$ to A transition in the second position of codon 12, while both $G$ to $A$ transitions and $G$ to $T$ transversions at the second position of codon 12 are frequently observed in human pancreatic cancers [43,44].

The $p 16^{I N K 4 A} / C D K N 2 A$ is known to be a tumor suppressor gene located at chromosome 9p that is inactivated in most pancreatic ductal carcinomas in humans (80-95\%) by intragenic mutations (40\%), homozygous deletions $(40 \%)$ or hypermethylation of its promoter region $(15 \%)[45,47,48]$. The protein encoded by 16 is an inhibitor of cyclin-dependent kinase and regulates the cell cycle by activation of RB proteins. Frequent alteration of $p 16(\sim 93 \%)$ has also been reported in BOP-induced pancreatic tumors in hamsters and the majority of changes involve aberrant methylation (47\%) or homozygous deletion (37\%) [49].

DPC4/SMAD4 is a tumor suppressor gene located at chromosome 18q21.1 which encodes a protein associated with the TGF- $\beta$ signaling pathway. DPC4/SMAD4 is inactivated in $50 \%$ of pancreatic adenocarcinomas in humans by homozygous deletions (30\%) or intragenic mutations in one allele coupled with loss of heterozygosity (LOH) (20\%) [50]. On the other hand, Dpc4/Smad4 alterations are rare in BOP-induced pancreatic tumors in hamsters (8\%) [51].

DCC is a tumor suppressor gene located at chromosome 18q21.3, which encodes a protein with homology to cell adhesion receptors. Expression has been found to be lost in $50 \%$ of human pancreatic 
adenocarcinomas [52] and also in 50\% of BOP-induced pancreatic tumors in hamsters [53]. In addition, DCC expression is reduced or lost in poorly differentiated or undifferentiated pancreatic cancer cell lines, whereas it is conserved in the more differentiated ones [52,37].

p53 is the most frequently altered tumor suppressor gene in various cancers, its protein being a transcription factor which regulates cell cycle and apoptosis. p53 is located at chromosome 17p and frequently inactivated by $\mathrm{LOH}$ and mutations in 40 to $75 \%$ of pancreatic adenocarcinomas in humans [34,45,54-56]. Overexpression of p53 protein can be detected in the nuclei of p53-mutated cells $[54,55]$. On the other hand, there is no evidence of p53 mutations in primary tumors in BOP-treated hamsters [57].

FHIT gene is a putative tumor suppressor gene located at chromosome 3p14, which is expressed in normal pancreatic ductular cells and is altered in pancreatic cancers [58]. Exogenous expression of FHIT in human pancreatic cancer cells causes cell cycle arrest and apoptosis [59] and loss of full length transcripts is frequent in primary pancreatic cancers of humans (62\%) [58] and BOP-treated hamsters (73\%) [60].

In addition to these gene alterations, increased protein expression, such as telomerase [61,62], midkine [63,64], cyclooxygenase-2 (COX-2) [65], metalloproteinase (MMP)-2, MMP-9 and membrane type 1-MMP [66,67] are shown in hamsters as in humans.

These findings indicate that multiple gene alterations and changes in protein expression observed in human pancreatic cancers are similarly involved in the BOP-induced hamster pancreatic ductal carcinogenesis model, underlining its utility for studying methods for pancreatic cancer prevention.

\section{Modifying Factors in the Experimental Pancreatic Carcinogenesis Models}

In addition to cigarette smoking, a well-known cause of pancreatic cancer, epidemiological studies have shown that chronic pancreatitis, obesity and diabetes mellitus are risk factors [68]. Using experimental animal models including mainly the BOP-induced pancreatic carcinogenesis model in hamsters, these and other possible promotive and suppressive factors in pancreatic carcinogenesis have been studied.

\subsection{Obesity and Diabetes}

Dietary fat has modifying effects on pancreatic carcinogenesis. It has been shown that a high-corn oil diet increased pancreatic ductal adenocarcinoma development in BOP-treated hamsters as compared with a low-corn oil diet [69]. Furthermore, a diet containing beef tallow has been shown to increase pancreatic cancer development compared with a diet containing corn oil [70]. Type and composition of fat are considered to be important. Fish oil rich in n-3 polyunsaturated fatty acids has been demonstrated to reduce pancreatic tumor incidences and hepatic metastasis in the BOP-treated hamster model [71]. Enhancing effects of high fat diet and suppressive influence of n-3 polyunsaturated fatty acid-rich fish oil on development of precancerous lesions, PanINs, in K-ras mutated GEM models have also been reported [72,73]. Obesity-mediated enhancement of PanIN lesion development is associated with increased inflammation, and abrogation of TNFR1 signaling blocks tumor promotion [72]. On the other hand, n-3 polyunsaturated fatty acids ameliorate 
inflammation through inactivation of the NF-кB signaling pathway and inhibit cell proliferation through induction of cell cycle arrest and apoptosis [73,74].

Streptozotocin is known to induce diabetes through damage to islet cells and its modifying effects on pancreatic carcinogenesis have been studied in the BOP-treated hamster model, though the results are somewhat controversial. It has been reported that administration of streptozotocin alone caused islet cell tumors (44\%), pseudoductules (40\%), and ductular adenomas (12\%), while simultaneous treatment with streptozotocin (single i.v. injection, $30 \mathrm{mg} / \mathrm{kg}$ body weight) and BOP (single s.c. injection, $10 \mathrm{mg} / \mathrm{kg}$ body weight) resulted in a significantly higher incidence of ductular carcinomas than induced by BOP alone [75]. On the other hand, pretreatment with streptozotocin at a diabetogenic dose (50 mg/kg body weight, three-times i.p. injection) prevented pancreatic cancer development when BOP was subsequently administered [76]. These inhibitory effects of pretreatment were dependent on the severity of the diabetes and could be blocked with nicotinamide [77]. These findings indicate that streptozotocin has a tumorigenic activity at relatively low dose, but when administered before BOP treatment, streptozotocin-induced diabetes/loss of insulin production could prevent BOP-induced pancreatic cancer development through killing islet cells. However, enhancing effects of diabetes and insulin-resistance observed in obesity on growth of transplantable pancreatic cancer cells are nevertheless convincing [78-80].

\subsection{Pancreatitis}

Cerulein is an analogue peptide of cholecystokinin, and its chronic intraperitorial injection causes pancreatic hypertrophy, characterized by increased pancreatic weight, increased amylase content and acinar cell hyperplasia. Moreover, cerulein augments the carcinogenicity of $\mathrm{N}$-nitrobis(2hydroxypropyl)amine (BHP) in the hamster pancreas [81]. It is also reported that chronic pancreatitis caused by cerulein induces development of pancreatic ductal adenocarcinomas in GEM mice expressing K-ras ${ }^{\mathrm{G} 2 \mathrm{~V}}$ in acinar/centroacinar cells [31]. On the other hand, pancreatitis caused by common duct ligation before BOP injection decreased carcinoma development, while repeated induction of pancreatitis by common duct ligation after BOP administration resulted in enhanced development of carcinomas, with reference to both number and size [82].

Heavy alcohol drinking and cigarette smoking are major causes of pancreatitis in humans [83]. Epidemiological studies have shown that smoking and chronic pancreatitis are risk factors, whereas alcohol consumption itself has no direct relation [83,84]. However, in a transplacental induction model of pancreatic ductal cancer featuring NNK and EtOH treatment in the Syrian golden hamster, EtOH alone caused pancreatitis and hyperplasia, while NNK alone did not induce either [8], indicating a strong enhancing effect of pancreatitis on pancreatic carcinogenesis. It has also been reported that EtOH and nicotine promote pancreatic carcinogenesis in the DMBA-implanted mouse model $[85,86]$.

In addition, repeated induction of pancreatitis with choline-deficient diet combined with DL-ethionine and L-methionine after initiation with BOP has been demonstrated to cause rapid production of pancreatic carcinomas in hamsters [87]. 


\subsection{Others}

There is limited evidence suggesting that red meat is a cause of pancreatic cancer $[88,89]$. In addition to total intake, the method of meat preparation is also important. Grilled red meat is a risk factor [90]. Effects of mutagenic heterocyclic amines (HCA) formed during cooking of meat on pancreatic carcinogenesis were studied in the BOP-treated hamster model. Among HCAs, 3-amino1,4-dimethyl-5H-pyrido[4,3-b]indole (Trp-P-1) and 2-amino-3,4,8-trimethylimidazo[4,5-f]quinoxaline (4,8-DiMeIQx) caused increase in pancreatic carcinoma development in BOP-treated hamsters [91]. Dietary intake of DiMeIQx has also been shown to be associated with pancreatic cancer risk in man [92].

High intake of fruits, vitamin $\mathrm{C}$ and vitamin $\mathrm{E}$ are suggested to protect against pancreatic cancer $[88,93,94]$ and both vitamins have been found to exert protective effects on BOP-induced pancreatic cancer development in hamsters [95].

\section{Cancer Prevention Targets for Humans and Evaluation in Experimental Pancreatic Carcinogenesis Models}

From the etiology of pancreatic cancer, possible methods for prevention are: (1) avoiding carcinogenic $N$-nitrosoamine exposure such as cigarette smoke; (2) body weight control by diets and physical activity; (3) use of anti-hyperlipidemic and/or anti-diabetic agents; (4) use of antiinflammatory agents.

Epidemiological studies have suggested that several agents having anti-hyperlipidemic, antidiabetic or anti-inflammatory activities may have chemopreventive potential against pancreatic cancer [96]. Statins are cholesterol-lowering agents and also inhibit membrane-binding of the Ras protein, and are reported to reduce pancreatic cancer cell invasion and metastasis [97]. A casecontrol study of half a million veterans demonstrated a significant reduction of pancreatic cancer risk in statin users (adjusted OR = 0.37) [98], while meta-analysis of 12 studies showed no evidence of association between statin use and pancreatic cancer risk $(R R=0.88)$ [99]. Aspirin is a most frequently used nonsteroidal anti-inflammatory drug (NSAID) and has been reported to reduce cancer risk in several organs such as in the colon [100]. In the pancreas, epidemiological data on aspirin use are controversial [101,102]. A cohort study of post-menopausal women has shown that current use of aspirin is associated with a reduced risk of pancreatic cancer (adjusted RR $=0.57$ ) [103], whereas another cohort study of nurses demonstrated that more than 20 years of regular aspirin use is associated with increased risk $(\mathrm{RR}=1.58)$ [104]. Metformin, an anti-diabetic drug, activates AMP-activated protein kinase (AMPK) and inhibits pancreatic cancer growth $[105,106]$. A hospitalbased case-control study has shown that metformin use is associated with reduced risk $(\mathrm{OR}=0.38)$, while insulin or insulin secretagogue use is associated with increased risk ( $O R=1.78$ ) of pancreatic cancer in diabetic patients [107]. However, there is still no report of cohort study or randomizedcontrol trial on metformin use. Since incidence of pancreatic cancer is relatively low compared with colon, breast and prostate cancers, prospective studies need quite a large population. In addition, randomized control studies are difficult, because the diseases such as hyperlipidemia and diabetes should be properly cared for. Therefore, evidences provided by preclinical studies including in vivo carcinogenesis studies using animal models are considered to be very important to evaluate the 
chemopreventive efficacy and mechanisms of these agents. Factors related to insulin resistance and inflammation are candidate targets for pancreatic cancer prevention. Table 2 shows chemopreventive agents evaluated in BOP-induced pancreatic carcinogenesis.

Table 2. Chemopreventive agents of $N$-nitrosobis(2-oxopropyl)amine (BOP)-induced pancreatic carcinogenesis in hamsters.

\begin{tabular}{|c|c|c|}
\hline Compounds & Mechanistic categories & Ref. \\
\hline \multicolumn{3}{|c|}{ Anti-hyperlipidemic/diabetic agents } \\
\hline Pioglitazone & PPAR $\gamma$ ligand & [113] \\
\hline Metformin & AMPK activator & [114] \\
\hline \multicolumn{3}{|c|}{ Anti-inflammatory agents } \\
\hline Indomethacin & NSAID & [119] \\
\hline Phenylbutazone & NSAID & [119] \\
\hline NO-ASA & NO-NSAID & [121] \\
\hline Nimesulide & COX-2 inhibitor & [118] \\
\hline Celecoxib/Zileuton & COX-2/5-LOX inhibitors & [127] \\
\hline ONO-1714 & iNOS inhibitor & [131] \\
\hline \multicolumn{3}{|l|}{ Others } \\
\hline OPB-3206 & MMP-2 inhibitor & {$[66]$} \\
\hline Protochatechuic acid & Antioxidant & [135] \\
\hline GTE & Antioxidant & [136] \\
\hline BHA & Antioxidant & [137] \\
\hline Sarcophytol A & Anti-tumor promoter & [138] \\
\hline Methionine & Essential amino acid & [139] \\
\hline PEITC & Cytochrome P450 suppressor & [140] \\
\hline PPITC & Cytochrome P450 suppressor & [143] \\
\hline PBITC & Cytochrome P450 suppressor & [144] \\
\hline BITC & Cytochrome P450 suppressor & [145] \\
\hline Sulforaphane & Anti-oxidative enzyme inducer & [145] \\
\hline Aloe arborescens & Detoxyfiying enzyme inducer & [146] \\
\hline Oltipraz & Nrf2 activator & [147] \\
\hline
\end{tabular}

\subsection{Anti-Hyperlipidemic/Diabetic Agents}

It has been reported that high cholesterol intake is associated with an increased risk of pancreatic cancer [108]. Smoking is associated with metabolic syndrome, and nicotine elevates serum triglyceride levels [109,110]. Obesity and diabetes are also closely associated with hyperlipidemia and hyperinsulinemia [111,112]. Interestingly, Syrian golden hamsters are in a hyperlipidemic state even under normal diet conditions, and pioglitazone, a ligand of peroxizome proliferator-activated receptor (PPAR) $\gamma$, has demonstrated to improve hyperlipidemia and suppress development of ductal adenocarcinomas in BOP-treated hamsters; the ductal adenocarcinoma incidences in the BOP $+800 \mathrm{ppm}$ pioglitazone group and the BOP alone group were $38 \%$ vs. $80 \%(P<0.01)$ and the multiplicities were $0.55 \pm 0.15$ vs. $1.37 \pm 0.22(P<0.01)$, respectively [113]. In addition, the incidences of bile duct tumors in BOP-treated hamsters were clearly suppressed by pioglitazone [113]. Metformin, an activator of AMPK, has also been shown to decrease serum insulin levels and suppress development of 
hyperplastic, dysplastic and malignant ductal lesions in the pancreas of BOP-treated hamsters on a high fat diet condition [114]. Pioglitazone and metformin are both anti-diabetic drugs which improve insulin resistance [115].

\subsection{Anti-inflammatory Agents}

Expression of COX-2 is up-regulated in PanIN and adenocarcinomas in humans and BOP-treated hamsters [64,116-118] and inhibition of prostanoid synthesis by NSAIDs, such as indomethacin and phenylbutazone, has been shown to reduce the development of precancerous lesions (atypical hyperplasia) and adenocarcinoma in the hamster model [119,120]. Whereas suppressive effects of aspirin were not significant, nitric oxide (NO)-donating aspirin, NO-ASA, has potent activity to prevent pancreatic cancer, especially arresting the transition from PanIN2 to PanIN3 and carcinoma, in BOP-treated hamsters [121]. It has also been reported that another COX-inhibitor, ibuprofen, reduces pancreatic cancer development in the hamster transplacental model with NNK + EtOH [122]. In GEM models, aspirin treatment has been shown to delay progression of PanINs in $L s L-K r a s^{G 12 D}$; Pdx1-Cre mice and to partially inhibit development of invasive cancers in LsL- Kras ${ }^{G 12 D}$; LsL-Trp53 ${ }^{R 172 H}$; Pdx1-Cre mice [123]. Furthermore, a selective COX-2 inhibitor, nimesulide, has been demonstrated to suppress development of precancerous lesions (atypical hyperplasia) and adenocarcinoma in BOP-treated hamsters [118]. In addition, inhibition of COX-2 by nimesulide delayed the appearance of PanIN-2 and PanIN-3 lesions in a conditional Kras ${ }^{\mathrm{G} 2 \mathrm{D}}$ mouse model, indicating the importance of prostaglandin synthesis by COX-2 in the early stage of pancreatic carcinogenesis [124]. In addition to COX-2, 5-LOX is also up-regulated in the ductal cells of PanIN and adenocarcinomas in humans, BOP-treated hamsters and Elastase-Kras mice [125,126]. Receptors of the downstream 5-LOX metabolite, leukotriene $\mathrm{B}_{4}$, have been reported to be expressed in human pancreatic cancer tissues [125] and combination of COX-2-inhibition by Celebrex and 5-LOXinhibition by Zyflo has shown to significantly decrease liver metastasis by pancreatic cancers in BOPtreated hamsters [127]. MK886, an inhibitor of 5-LOX activating protein FLAP, also reduced pancreatic cancer development in the hamster transplacental model with NNK + EtOH [122].

Increased expression of iNOS is also observed in pancreatic adenocarcinomas in humans and hamsters [128-131], perhaps involving K-ras activation [132]. Inhibition of iNOS by a selective iNOS inhibitor ONO-1714 suppressed development of precancerous lesions (atypical hyperplasia) and invasive adenocarcinomas in BOP-treated hamsters [131].

\subsection{Others}

Expression of MMP-2 is increased in precancerous lesions and adenocarcinomas, and proMMP-2 is highly activated in pancreatic carcinomas in humans and hamsters [133,66]. Inhibition of proMMP-2 activation by the MMP inhibitor OPB-3206 has been demonstrated to suppress pancreatic cancer development in BOP-treated hamsters under a rapid production protocol [66]. Another MMP inhibitor, RO 28-2653, has been reported to inhibit liver metastasis in the BOP-induced pancreatic carcinogenesis model, directly indicating roles for MMP-2 in cancer progression [134].

Protochatechuic acid, green tea extracts (GTE) and butylated hydroxyanisole (BHA) are antioxidative agents which have demonstrated inhibitory effects on pancreatic cancer development during 
the post-initiation stage of the BOP-initiated hamster model [135-137]. Sarcophytol A, which is known to be an anti-tumor promoter, and methionine, which is an essential amino acid and associated with anti-oxidation, have also been shown to suppress pancreatic carcinogenesis in the BOP-treated hamster model [138,139].

Phenethyl isothiocyanate (PEITC), a natural constituent of cruciferous vegetables, has been demonstrated to be a potent chemopreventive agent in the initiation phase of pancreatic carcinogenesis in hamsters initiated with BOP [140,141], while not affecting the post-initiation phase [142]. Synthetic analogues of PEITC, such as 3-phenylpropyl isothiocyanate (PPITC), 4-phenylbutyl isothicyanate (PBITC) and benzyl isothicianate (BITC), and sulforaphane, Aloe arborescens and oltipraz have also been shown to suppress the initiation phase of BOP-induced pancreatic carcinogenesis through inhibition of activating (phase I) enzymes or activation of detoxifying (phase II) enzymes related to metabolism of BOP [143-147].

Nicotine-derived nitrosamine NNK stimulates release of noradrenaline/adrenaline by binding to alpha7 nicotinic acetylcholine receptors and activates beta-adrenergic receptors, resulting in proliferation of human pancreatic epithelial cells through cAMP-dependent signaling [148,149]. A beta-blocker propranolol has been shown to suppress the development of pancreatic cancer induced in the hamster transplacental model with NNK + EtOH [150].

Angiotensin-I-converting enzyme (ACE) and angiotensin II type 1 receptor are upregulated in human pancreatic cancer tissues and co-localized with vascular endothelial growth factor (VEGF) in malignant ducts and in stromal cells [151]. The ACE inhibitor enalapril has been demonstrated to delay progression of PanINs in $L s L-K r a s^{G 12 D}$; Pdx1-Cre mice and to partially inhibit development of invasive cancer in $L s L-K_{r a s}^{G 12 D}$; LsL-Trp53 ${ }^{R 172 H}$; Pdx1-Cre mice [123].

An epidermal growth factor receptor inhibitor, gefitinib, has been demonstrated to suppress development of PanINs and cancer in $L s L-K_{r a s}{ }^{G 12 D}$; p48-Cre mice [152]. Furthermore, a src kinase inhibitor, dasatinib, has been shown to suppress metastasis in $L s L-K_{r a s}{ }^{G 12 D}$; LsL-Trp53 ${ }^{R 172 H}$; Pdx1-Cre; Z/EGFP mice, although there are no effects on proliferation and no survival advantage [153]. In addition, synthetic oleanane triterpenoids CDDO-methyl ester or CDDO-ethyl amide, the rexinoid LG100268, or the combination have been shown to increase survival in $L s L-K r a s^{G 12 D}$; LsL$\operatorname{Trp}^{2} 3^{R 172 H}$; Pdx1-Cre mice [154].

\section{Conclusions}

As shown above, the BOP-induced pancreatic carcinogenesis model in Syrian golden hamsters has genotypic and phenotypic similarities to the human case, and is a useful animal model for investigation of cancer prevention, even though the mechanistic analyses are a little difficult due to its limited genetic information. In this model, both precancerous lesions and advanced ductal carcimomas are assessable, and most of the BOP-treated hamsters develop pancreatic ductal carcinomas within six months. On the other hand, DMBA-induced pancreatic carcinogenesis models in rats and mice are considered to be not suitable for prevention studies, from the viewpoints of pathological origin of cancers and technical difficulty with neoplastic lesions developing only where carcinogen is implanted. GEM models are powerful for verifying the oncogenic mechanisms, but the process of carcinogenesis is pathologically different from the vast majority of human cases. Recently, several 
chemoprevention studies using GEM models have been reported [73,123,124,126, 152-154], mainly of two types. One focuses on suppression of PanIN development in $L s L-K r a s^{G 12 D}$; Pdx1-Cre mice or $L s L-K_{r a s}{ }^{G 12 D}$; p48-Cre mice. In this system, incidences of pancreatic cancer are low ( $20 \%$ at one year) [155], and therefore, it is difficult to obtain statistically significant results for cancer development. The PanIN lesions in GEM mice have similar phenotypes to humans, such as COX-2 [124] and LOX-5 [126] expression, but the pathological process of development of early lesions is quite different from human cases. Thus, the usefulness of this model may be limited regarding early detection and prevention of human pancreatic cancer. In suppression studies on cancer development or prolonged survival with $L s L$ - Kras ${ }^{G 12 D}$; LsL-Trp53 ${ }^{R 172 H}$; Pdx1-Cre mice, the GEM animals mimic the genetics of human pancreatic cancer and quickly develop pancreatic ductal carcinomas. This model may be more suitable for therapeutic studies than for prevention.

In humans, a number of epidemiological studies have suggested reduced pancreatic cancer risk with use of anti-hyperlipidemic/diabetic or anti-inflammatory agents. However, this is difficult to prove in randomized-control studies, because of the relatively low incidence of pancreatic cancer in humans and the absence of early biomarkers to predict pancreatic cancer. Thus, in vivo carcinogenesis studies using animal models are important to support the epidemiological findings and provide direct evidence. Some anti-hyperlipidemic and anti-inflammatory agents have indeed been shown to exert suppressive effects on pancreatic carcinogenesis in animal models including that with BOP-initiation in the hamster, indicating that factors related to hyperlipidemia, insulin resistance and inflammation are candidate targets for pancreatic cancer prevention.

\section{Acknowledgements}

The work performed in our laboratory was supported in part by: Grants-in-Aid for Cancer Research from the Ministry of Health, Labour and Welfare of Japan and Management Expenses Grants from the Government to the National Cancer Center (21-2-1); a grant of the Research Grant of the Princess Takamatsu Cancer Research Fund (08-24009); a Grant-in-Aid for Scientific Research from the Japan Society for the Promotion of Science (J.S.P.S.); and a grant of the Third-Term Comprehensive 10-Year Strategy for Cancer Control from the Ministry of Health, Labour and Welfare of Japan.

M. Hori is an Awardee of Research Resident Fellowship from the Foundation for Promotion of Cancer Research (Japan) for the Third-Term Comprehensive 10-Year Strategy for Cancer Control.

\section{References}

1. Matsuno, S.; Egawa, S.; Shibuya, K.; Shimamura, H.; Sunamura, M.; Takeda, K.; Katoh, H.; Okada, S.; Suda, K.; Nakao, A.; Isaji, S.; Hiraoka, T.; Hosotani, R.; Imaizumi, T. Pancreatic cancer: Current status of treatment and survival of 16071 patients diagnosed from 1981-1996, using the Japanese National Pancreatic Cancer Database. Int. J. Clin. Oncol. 2000, 5, 153-157.

2. Standop, J.; Schneider, M.B.; Ulrich, A.; Pour, P.M. Experimental animal models in pancreatic carcinogenesis: Lessons for human pancreatic cancer. Dig. Dis. 2001, 19, 24-31.

3. Pour, P.; Kruger, F.W.; Althoff, J.; Cardesa, A.; Mohr, U. Cancer of the pancreas induced in the Syrian golden hamster. Am. J. Pathol. 1974, 76, 349-358. 
4. Pour, P.; Althoff, J.; Krüger, F.W.; Mohr, U. A potent pancreatic carcinogen in Syrian hamsters: $N$-nitrosobis(2-oxopropyl)amine. J. Natl. Cancer Inst. 1977, 58, 1449-1453.

5. Pour, P. Experimental pancreatic ductal (ductular) tumors. Monogr. Pathol. 1980, 21, 111-139.

6. Pour, P.M.; Runge, R.G.; Birt, D.; Gingell, R.; Lawson, T.; Nagel, D.; Wallcave, L.; Salmasi, A.H. Current knowledge of pancreatic carcinogenesis in the hamster and its relevance to the human disease. Cancer 1981, 47, 1573-1587.

7. Pour, P.; Althoff, J.; Takahashi, M. Early lesions of pancreatic ductal carcinoma in the hamster model. Am. J. Pathol. 1977, 88, 291-308.

8. Schüller, H.M.; Jorquera, R.; Reichert, A.; Castonguay, A. Transplacental induction of pancreas tumors in hamsters by ethanol and the tobacco-specific nitrosamine 4-(methylnitrosamino)-1-(3pyridyl)-1-butanone. Cancer Res. 1993, 53, 2498-2501.

9. Longnecker, D.S.; Curphey, T.J. Adenocarcinoma of the pancreas in azaserine-treated rats. Cancer Res. 1975, 35, 2249-2258.

10. Longnecker, D.S.; Curphey, T.J.; Lilja, H.S.; French, J.I.; Daniel, D.S. Carcinogenicity in rats of the nitrosourea amino acid $N$ delta-( $N$-methyl- $N$-nitrosocarbamoyl)-L-ornithine. Environ. Pathol. Toxicol. 1980, 4, 117-129.

11. Longnecker, D.S.; Curphey, T.J.; Kuhlmann, E.T.; Schaeffer, B.K. Experimental induction of pancreatic carcinomas in the hamster with $N$ delta-( $N$-methyl- $N$-nitrosocarbamoyl)-L-ornithine. J. Natl. Cancer Inst. 1983, 71, 1327-1336.

12. Pour, P.; Salmasi, S.; Runge, R.; Gingell, R.; Wallcave, L.; Nagel, D.; Stepan, K. Carcinogenicity of $N$-nitrosobis(2-hydroxypropyl)amine and $N$-nitrosobis(2-oxopropyl)amine in MRC rats. J. Natl. Cancer Inst. 1979, 63, 181-190.

13. Sakano, K.; Takahashi, M.; Mutoh, M.; Niho, N.; Komiya, M.; Sato, H.; Tanaka, T.; Sugimura, T.; Wakabayashi, K. Enhanced thyroid carcinogenicity of $N$-nitrosobis(2-oxopropyl)amine in Otsuka Long-Evans Tokushima Fatty rats, a model of type II diabetes mellitus. Carcinogenesis 2007, 28, 2193-2198.

14. Fujii, K.; Hayakawa, T.; Kikuchi, M. Tumor induction in mice administered neonatally with bis(2-oxopropyl)nitrosamine. Tohoku J. Exp. Med. 1994, 174, 361-368.

15. Scarpelli, D.G.; Rao, M.S.; Reddy, J.K. Studies of pancreatic carcinogenesis in different animal models. Environ. Health Persp. 1984, 56, 219-227.

16. Rao, M.S. Animal models of exocrine pancreatic carcinogenesis. Cancer Metast. Rev. 1987, 6, 665-676.

17. Longnecker, D. Experimental pancreatic cancer: Role of species, sex and diet. Bull. Cancer 1990, 77, 27-37.

18. Dissin, J.; Mills, L.R.; Mains, D.L.; Black, O., Jr.; Webster, P.D., 3rd. Experimental induction of pancreatic adenocarcinoma in rats. J. Natl. Cancer Inst. 1975, 55, 857-864.

19. Bockman, D.E.; Black, O., Jr.; Mills, L.R.; Mainz, D.L.; Webster, P.D. 3rd. Fine structure of pancreatic adenocarcinoma induced in rats by 7,12-dimethylbenz(a)anthracene. J. Natl. Cancer Inst. 1976, 57, 931-936.

20. Osvaldt, A.B.; Wendt, L.R.; Bersch, V.P.; Backes, A.N.; de Cássia, A.; Schumacher, R.; Edelweiss, M.I.; Rohde, L. Pancreatic intraepithelial neoplasia and ductal adenocarcinoma induced by DMBA in mice. Surgery 2006, 140, 803-809. 
21. Jimenez, R.E.; Z’graggen, K.; Hartwig, W.; Graeme-Cook, F.; Warshaw, A.L.; Castillo, C.F. Immunohistochemical characterization of pancreatic tumors induced by dimethylbenzanthracene in rats. Am. J. Pathol. 1999, 154, 1223-1229.

22. Z’graggen K.; Warshaw, A.L.; Welner, J.; Graeme-Cook, F.; Jimenez, R.E.; Castillo, C.F. Promoting effects of a high-fat/high-protein diet in DMBA-induced ductal pancreatic cancer in rats. Ann. Surgery 2001, 233, 688-695.

23. Hruban, R.H.; Adsay, N.V.; Albores-Saavedra, J.; Anver, M.R.; Biankin, A.V.; Boivin, G.P.; Furth, E.E.; Furukawa, T.; Klein, A.; Klimstra, D.S.; Kloppel, G.; Lauwers, G.Y.; Longnecker, D.S.; Luttges, J.; Maitra, A.; Offerhaus, G.J.; Pérez-Gallego, L.; Redston, M.; Tuveson, D.A. Pathology of genetically engineered mouse models of pancreatic exocrine cancer: Consensus report and recommendations. Cancer Res. 2006, 66, 95-106.

24. Grippo, P.J.; Nowlin, P.S.; Demeure, M.J.; Longnecker, D.S.; Sandgren, E.P. Preinvasive pancreatic neooplasia of ductal phenotype induced by acinar cell targeting of mutant Kras in transgenenic mice. Cancer Res. 2003, 63, 2016-2019.

25. Hingorani, S.R.; Petricoin, E.F.; Maitra, A.; Rajapakse, V.; King, C.; Jacobetz, M.A.; Ross, S.; Conrads, T.P.; Veenstra, T.D.; Hitt, B.A.; Kawaguchi, Y.; Johann, D.; Liotta, L.A.; Crawford, H.C.; Putt, M.E.; Jacks, T.; Wright, C.V.; Hruban, R.H.; Lowy, A.M.; Tuveson, D.A. Preinvasive and invasive ductal pancreatic cancer and its early detection in the mouse. Cancer Cell 2003, 4, 437-450.

26. Deramaudt, T.; Rustgi, A.K. Mutant KRAS in the initiation of pancreatic cancer. Biochem. Biophys. Acta 2005, 1756, 97-101.

27. Aguirre, A.J.; Bardeesy, N.; Sinha, M.; Lopez, L.; Tuveson, D.A.; Horner, J.; Redston, M.S., DePinho, R.A. Activated Kras and Ink4a/Arf deficiency cooperate to produce metastatic pancreatic ductal adeocarcinoma. Genes \& Dev. 2003, 17, 3112-3126.

28. Hingorani, S.R.; Wang, L.; Multani, A.S.; Combs, C.; Deramaudt, T.B.; Hruban, R.H.; Rustgi, A.K.; Chang, S.; Tuveson, D.A. Trp53 ${ }^{R 172 H}$ and $\operatorname{Kras}^{G 12 D}$ cooperate to promote chromosomal instability and widely metastatic pancreatic ductal adenocarcinoma in mice. Cancer Cell 2005, 7, 469-483.

29. Kijima, K.; Vickers, S.M.; Adsay, N.V.; Jhala, N.C.; Kim, H.; Schoeb, T.R.; Grizzle, W.E.; Klug, C.A. Inactivation of Smad4 accelerates KrasG12D-mediated pancreatic neoplasia. Cancer Res. 2007, 67, 8121-8130.

30. Ijichi, H.; Chytil, A.; Gorska, A.E.; Aakre, M.E.; Fujitani, Y.; Fujitani, S.; Wright, C.V.E.; Moses, H.L. Aggressive pancreatic ductal adenocarcinoma in mice caused by pancreas-specific blockade of transforming growth factor-beta signaling in cooperation with active Kras exoression. Genes Dev. 2006, 20, 3147-3160.

31. Guerra, C.; Schuhmacher, A.J.; Cañamero, M.; Grippo, P.J.; Verdaguer, L.; Pérez-Gallego, L.; Dubus, P.; Sandgren, E.P.; Barbacid, M. Chronic pancreatitis is essential for induction of pancreatic ductal adenocarcinoma by K-Ras oncogenes in adult mice. Cancer Cell 2007, 11, 291-302.

32. Ueda, S.; Fukamachi, K.; Matsuoka, Y.; Takasuka, N.; Takeshita, F.; Naito, A.; Iigo, M.; Alexander D.B.; Moore, M.A.; Saito, I.; Ochiya, T.; Tsuda, H. Ductal origin of pancreatic adenocarcinomas induced by conditional activation of a human Ha-ras oncogene in rat pancreas. Carcinogenesis 2006, 27, 2497-2510. 
33. Fukamachi, K.; Tanaka, H.; Hagiwara, Y.; Ohara, H.; Joh, T.; Iigo, M.; Alexander, D.B.; Xu, J.; Long, N.; Takigahira, M.; Yanagihara, Y.; Hino, O.; Saito, I.; Tsuda, H. An animal model of preclinical diagnosis of pancreatic ductal carcinomas. Biochem. Biophys. Res. Commun. 2009, 390, 636-641.

34. Hruban, R.H.; Wilentz, R.E.; Kern, S.E. Genetic progression in the pancreatic ducts. Am. J. Pathol. 2000, 156, 1821-1825.

35. Bardeesy, N.; DePinho, R.A. Pancreatic cancer biology and genetics. Nature Rev. 2002, 2, 897-909.

36. Moore, P.; Beghelli, S.; Zamboni, G.; Scarpa, A. Genetic abnormalities in pancreatic cancer. Mol. Cancer 2003, 2, 1-7.

37. Tarafa, G.; Villanueva, A.; Farré, L.; Rodríguez, J., Musulén, E.; Reyes, G.; Seminago, R.; Olmedo, E.; Paules, A.B.; Peinado, M.A.; Bachs, O.; Capellá, G. DCC and SMAD4 alterations in human colorectal and pancreatic tumor dissemination. Oncogene 2000, 19, 546-555.

38. Konishi, Y.; Tsutsumi, M.; Tsujiuchi, T. Mechanistic analysis of pancreatic ductal carcinogenesis in hamsters. Pancreas 1998, 16, 300-306.

39. Tsujiuchi, T.; Tsutsumi, M.; Konishi, Y. Molecular aspects during multi-step chemical induced carcinogenesis in the lung and pancreas. J. Toxicol. Pathol. 2003, 16, 133-138.

40. van Kranen, H.J.; Vermeulen, E.; Schoren, L.; Bax, J.; Woutersen, R.A.; van Iersel, P.; van Kreijl, C.F.; Scherer, E. Activation of c-K-ras is frequent in pancreatic carcinomas of Syrian hamsters, but is absent in pancreatic tumors of rats. Carcinogenesis 1991, 12, 1477-1482.

41. Cerny, W.L.; Mangold, K.A.; Scarpelli, D.G. K-ras mutation is an early event in pancreatic duct carcinogenesis in the Syrian golden hamster. Cancer Res. 1992, 52, 4507-4513.

42. Chang, K.W.; Laconi, S.; Mangold, K.A.; Hubchak, S.; Scarpelli, D.G. Multiple genetic alterations in hamster pancreatic ductal adenocarcinomas. Cancer Res. 1995, 55, 2560-2568.

43. Burmer, G.C.; Rabinovitch, P.S.; Loeb, L.A. Frequency and spectrum of c-Ki-ras mutations in human sporadic colon carcinoma, carcinomas arising in ulcerative colitis, and pancreatic adenocarcinoma. Environ. Health Persp. 1991, 93, 27-31.

44. Mu, D.; Peng, Y.; Xu, Q. Values of mutations of K-ras oncogene at codon 12 in detection of pancreatic cancer: 15-year experience. World J. Gastroenterol. 2004, 10, 471-475.

45. Saif, M.W.; Karapanagiotou, L.; Syrigos, K. Genetic alterations in pancreatic cancer. World J. Gastroenterol. 2007, 7, 4423-4430.

46. Terhune, P.G.; Phifer, D.M.; Tosteson, T.D.; Longnecker, D.S. K-ras mutation infocal proliferative lesions of human pancreas. Cancer Epidem. Biomark. Prev. 1998, 7, 515-521.

47. Caldas, C.; Hahn, S.A.; da Costa, L.T.; Redston, M.S.; Schutte, M.; Seymour, A.B.; Weinstein, C.L.; Hruban, R.H.; Yeo, C.J.; Kern, S.E. Frequent somatic mutations and homozygous deletions of the p16 (MTS1) gene in pancreatic adenocarcinoma. Nat. Genet. 1994, 8, 27-32.

48. Hruban, R.H.; Offerhaus, G.J.A.; Kern, S.E.; Goggins, M.; Wilentz, R.E.; Yeo, C.J. Tumorsuppressor genes in pancreatic cancer. J. Hepatobilary Pancreat. Surg. 1998, 5, 383-391.

49. Li, J.; Weghorst, C.M.; Tsutsumi, M.; Poi, M.J.; Knobloch, T.J.; Casto, B.C.; Melvin, W.S.; Tsai, M.; Muscarella, P. Frequent $p 16^{I N K 4 A} / C D K N 2 A$ alterations in chemically induced Syrian golden hamster pancreatic tumors. Carcinogenesis 2004, 25, 263-268. 
50. Hahn, S.A.; Schutte, M.; Hoque, A.T.; Moskaluk, C.A.; da Costa, L.T.; Rozenblum, E.; Weinstein, C.L.; Fischer, A.; Yeo, C.J.; Hruban, R.H.; Kern, S.E. DPC4, a candidate tumor suppressor gene at human chromosome 18q21.1. Science 1996, 271, 350-353.

51. Shimizu, K.; Kitahashi, T.; Fujii, H.; Tsutsumi, M.; Mori, T.; Honoki, K.; Tsujiuchi, T. Alterations in the Smad4 gene in hamster pancreatic duct adenocarcinomas and established cell lines. Oncol. Rep. 2006, 16, 85-89.

52. Höhne, M.W.; Halatsch, M.E.; Kahl, G.F.; Weinel, R.J. Frequent loss of expression of the potential tumor suppressor gene DCC in ductal pancreatic adenocarcinoma. Cancer Res. 1992, 52, 2616-2619.

53. Chang, K.W.; Laconi, S.; Mangold, K.A.; Hubchak, S.; Scarpelli, D.G. Multiple genetic alterations in hamster pancreatic ductal adenocarcinomas. Cancer Res. 1995, 55, 2560-1568.

54. Barton, C.M.; Staddon, S.L.; Hughes, C.M.; Hall, P.A.; O'Sullivan, C.; Klöppel, G.; Theis, B.; Russell, R.C.; Neoptolemos, J.; Williamson, R.C.; Lane, D.P.; Lemoine, N.R. Abnormalities of the p53 tumour suppressor gene in human pancreatic cancer. Br. J. Cancer 1991, 64, 1076-1082.

55. Ruggeri, B.; Zhang, S.Y.; Caamano, J.; DiRado, M.; Flynn, S.D.; Klein-Szanto, A.J. Human pancreatic carcinomas and cell lines reveal frequent and multiple alterations in the $p 53$ and $R b-1$ tumor-suppressor genes. Oncogene 1992, 7, 1503-1511.

56. Rozenblum, E.; Schutte, M.; Goggins, M.; Hahn, S.A.; Panzer, S.; Zahurak, M.; Goodman, S.N.; Sohn, T.A.; Hruban, R.H.; Yeo, C.J.; Kern, S.E. Tumor-suppressive pathways in pancreatic carcinoma. Cancer Res. 1997, 57, 1731-1734.

57. Okita, S.; Tsutsumi, M.; Onji, M.; Konishi, Y. p53 mutation without allelic loss and absence of mdm-2 amplification in a transplantable hamster pancreatic ductal adenocarcinoma and derived cell lines but not primary ductal adenocarcinomas in hamsters. Mol. Carcinog. 1995, 13, 266-271.

58. Sorio, C.; Baron, A.; Orlandini, S.; Zamboni, G.; Pederzoli, P.; Huebner, K.; Scarpa, A. The FHIT gene is expressed in pancreatic ductular dells and is altered in pancreatic cancers. Cancer Res. 1999, 59, 1308-1314.

59. Gopalakrishnan, V.K.; Banerjee, A.G.; Vishwanatha, J.K. Effect of FHIT gene replacement on growth, cell cycle and apoptosis in pancreatic cancer cells. Pancreatol. 2003, 3, 293-302.

60. Tsijiuchi, T.; Sasaki, Y.; Kubozoe, T.; Konishi, Y.; Tsutsumi, M. Alterations in the Fhit gene in pancreatic duct adenocarcinomas induced by N-nitrosobis(2-oxopropyl)amine in hamsters. Mol. Carcinog. 2003, 36, 60-66.

61. Kobitsu, K.; Tsutsumi, M.; Tsujiuchi, T.; Suzuki, F.; Kido, A.; Okajima, E.; Fukuda, T.; Sakaki, T.; Konishi, Y. Shortened telomere length and increased telomerase activity in hamster pancreatic duct adeenocarcinomas and cell line. Mol. Carcinog. 1997, 18, 153-159.

62. Hiyama, E.; Kodama, T.; Shinbara, K.; Iwao, T.; Itoh, M.; Hiyama, K.; Shay, J.W.; Matsuura, Y.; Yokoyama, T. Telomerase activity is detected in pancreatic cancer but not in benign tumors. Cancer Res. 1997, 57, 326-331.

63. Tsutsumi, M.; Kadomatsu, K.; Tsujiuchi, T.; Sakitani, H.; Ikematsu, S.; Kubozoe, T.; Yoshimoto, M.; Marumatsu, T.; Sakuma, S.; Konishi, Y. Overexpression of midkine in pancreatic duct adenocarcinomas induced by $\mathrm{N}$-nitrosobis(2-oxopropyl)amine in hamsters and their cell line. Jpn. J. Cancer Res. 2000, 91, 979-986. 
64. Tsutsui, J.; Kadomatsu, K.; Matsubara, S.; Nakagawara, A.; Hamanoue, M.; Kakao, S.; Shimazu, H.; Ohi, Y.; Muramatsu, T. A new family of heparin-binding growth / differentiation factors: Increased midkine expression in Wilms' tumor and other human carcinomas. Cancer Res. 1993, 53, 1281-1285.

65. Crowell, P.L.; Schmidt, C.M.; Yip-Schneider, M.T.; Savage, J.J.; Hertzler, D.A. $2^{\text {nd }}$; Cummings, W.O. Cyclooxygenase-2 expression in hamster and human pancreatic neoplasia. Neoplasia 2006, 8, 437-445.

66. Iki, K.; Tsutsumi, M.; Kido, A.; Sakitani, H.; Takahama, M.; Yoshimoto, M.; Motoyama, M.; Tatsumi, K.; Tsunoda, T.; Konishi, Y. Expression of matrix metalloproteinase 2 (MMP-2), membrane-type 1 MMP and tissue inhibitor of metalloproteinase 2 and activation of proMMP-2 in pancreatic duct adenocarcinomas in hamsters treated with $\mathrm{N}$-nitrosobis(2-oxopropyl)amine. Carcinogenesis 1999, 20, 1323-1329.

67. Määttä, M.; Soini, Y.; Liakka, A.; Autio-Harmainen, H. Differential expression of matrix metalloproteinase (MMP)-2, MMP-9, and membrane type 1-MMP in hepatocellular and pancreatic adenocarcinoma: Implications for tumor progression and clinical prognosis. Clin. Cancer Res. 2000, 6, 2726-2734.

68. Michaud, D.S. Epidemiology of pancreatic cancer. Minerva Chir. 2004, 59, 99-111.

69. Birt, D.F.; Salmasi, S.; Pour, P.M. Enhancement of experimental pancreatic cancer in Syrian golden hamsters by dietary fat. J. Natl. Cancer Inst. 1981, 67, 1327-1332.

70. Birt, D.F.; Julius, A.D.; Dwork, E.; Hanna, T.; White, L.T.; Pour, P.M. Comparison of the effects of dietary beef tallow and corn oil on pancreatic carcinogenesis in the hamster model. Carcinogenesis 1990, 11, 745-748.

71. Heukamp, I.; Kilian, M.; Gregor, J.I.; Kiewert, C.; Schimke, I.; Kristiansen, G.; Walz, M.K.; Jacobi, C.A.; Wenger, F.A. Impact of polyunsaturated fatty acids on hepato-pancreatic prostaglandin and leukotriene concentration in ductal pancreatic cancer - Is there a correlation to tumor growth and liver metastasis? Prostaglandins Leukot. Essent. Fatty Acids 2006, 74, 223-233.

72. Khasawneh, J.; Schulz, M.D.; Walch, A.; Rozman, J.; Hrabe de Angelis, M.; Klingenspor, M.; Buck, A.; Schwaiger, M; Saur, D.; Schmid, R.M.; Klöppel, G.; Sipos, B.; Greten, F.R.; Arkan, M.C. Inflammation and mitochondrial fatty acid beta-oxidation link obesity to early tumor promotion. Proc. Natl. Acad. Sci. USA 2009, 106, 3354-3359.

73. Strouch, M.J.; Ding, Y.; Salabat, M.R.; Melstrom, L.G.; Adrian, K.; Quinn, C.; Pelham, C.; Rao, S.; Adrian, T.E.; Bentrem, D.J.; Grippo, P.J. A high omega-3 fatty acid diet mitigates murine pancreatic precancer development. J. Surg. Res. 2011, 165, 77-81.

74. Boutros, C.; Somasundar, P.; Razzak, A.; Helton, S.; Espat, N.J. Omega-3 fatty acids: Investigation from cytokine regulation to pancreatic cancer gene suppression. Arch. Surg. 2010, 145, 515-520.

75. Pour, P.M.; Patil, K. Modification of pancreatic carcinogenesis in the hamster model. X. Effect of streptozotocin. J. Natl. Cancer Inst. 1983, 71, 1059-1065.

76. Bell, R.H., Jr.; Strayer, D.S. Streptozotocin prevents development of nitrosamine-induced pancreatic cancer in the Syrian hamster. J. Surg. Oncol. 1983, 24, 258-262.

77. Bell, R.H., Jr.; McCullough, P.J.; Pour, P.M. Influence of diabetes on susceptibility to experimental pancreatic cancer. Am. J. Surg. 1988, 155, 159-164. 
78. Fisher, W.E.; McCullough, P.J.; Ray, M.B.; Rogers, D.H.; Bell, R.H., Jr. Diabetes enhances growth of pancreatic carcinoma cells. Surgery 1988, 104, 431-436.

79. Zyromski, N.J.; Mathur, A.; Pitt, H.A.; Wade, T.E.; Wang, S.; Nakshatri, P.; Swartz-Basile, D.A.; Nakshatri, H. Obesity potentiates the growth and dissemination of pancreatic cancer. Surgery 2009, 146, 258-263.

80. White, P.B.; True, E.M.; Ziegler, K.M.; Wang, S.S.; Swartz-Basile, D.A.; Pitt, H.A.; Zyromski, N.J. Insulin, Leptin, and tumoral adipocytes promote murine pancreatic cancer growth. J. Gastrointest. Surg. 2010, 14, 1888-1893.

81. Satake, K.; Mukai, R.; Kato, Y.; Umeyama, K. Effects of cerulein on the normal pancreas and on experimental pancreatic carcinoma in the Syrian golden hamster. Pancreas 1986, 1, 246-253.

82. Pour, P.M.; Takahashi, M.; Donnelly, T.; Stepan, K. Modification of pancreatic carcinogenesis in the hamster model. IX. Effect of pancreatitis. J. Natl. Cancer Inst. 1983, 71, 607-613.

83. Otsuki, M.; Tashiro, M. 4. Chronic pancreatitis and pancreatic cancer, lifestyle-related diseases. Intern. Med. 2007, 46, 109-113.

84. Go, V.L.W.; Gukovskaya, A.; Pandol, S.J. Alcohol and pancreatic cancer. Alcohol 2005, 35, 205-211.

85. Wendt, L.R.; Osvaldt, A.B.; Bersch, V.P.; Schumacher, R. de C.; Edelweiss, M.I.; Rohde, L. Pancreatic intraepithelial neoplasia and ductal adenocarcinoma induced by DMBA in mice: Effects of alcohol and caffeine. Acta Cir. Bras. 2007, 22, 202-209.

86. Bersch, V.P.; Osvaldt, A.B.; Edelweiss, M.I.; Schumacher, R. de C.; Wendt, L.R.; Abreu, L.P.; Blom, C.B.; Abreu, G.P.; Costa, L.; Piccinini, P.; Rohde, L. Effect of nicotine and cigarette smoke on an experimental model of intraepithelial lesions and pancreatic adenocarcinoma induced by 7,12-dimethylbenzanthracene in mice. Pancreas 2009, 38, 65-70.

87. Mizumoto, K.; Tsutsumi, M.; Denda, A.; Konishi, Y. Rapid production of pancreatic carcinoma by initiation with $\mathrm{N}$-nitroso-bis(2-oxopropyl)amine and repeated augmentation pressure in hamsters. J. Natl. Cancer Inst. 1988, 80, 1564-1567.

88. World Cancer Research Fund/American Institute for Cancer Research. Food, Nutrition, Physical Activity, and the Prevention of Cancer: A Global Perspective; AICR: Washington, DC, USA, 2007.

89. Hart, A.R.; Kennedy, H.; Harvey, I. Pancreatic cancer: A review of the evidence on causation. Clin. Gastroenterol. Hepatol. 2008, 6, 275-282.

90. Anderson, K.E.; Sinha, R.; Kulldorff, M.; Gross, M.; Lang, N.P.; Barber, C.; Harnack, L.; DiMagno, E.; Bliss, R.; Kadlubar, F.F. Meat intake and cooking techniques: Associations with pancreatic cancer. Mutat. Res. 2002, 506-507, 225-231.

91. Yoshimoto, M.; Tsutsumi, M.; Iki, K.; Sasaki, Y.; Tsujiuchi, T.; Sugimura, T.; Wakabayashi, K.; Konishi, Y. Carcinogenicity of heterocyclic amines for the pancreatic duct epithelium in hamsters. Cancer Lett. 1999, 143, 235-239.

92. Li, D.; Day, R.S.; Bondy, M.L.; Shinha, R.; Tguyen, N.T.; Evans, D.B.; Abbruzzese, J.L.; Hassan, M.M. Dietary mutagen exposure and risk of pancreatic cancer. Cancer Epidemiol. Biomarkers Prev. 2007, 16, 655-661.

93. Lin, Y.; Kikuchi, S.; Tamakoshi, A.; Yagyu, K.; Obata, Y.; Inaba, Y.; Kurosawa, M.; Kawamura, T.; Motohashi, Y.; Ishibashi, T. Dietary habits and pancreatic cancer risk in a cohort of middleaged and elderly Japanese. Nutr. Cancer 2006, 56, 40-49. 
94. Bravi, F.; Polesel, J.; Bosetti, C.; Talamini, R.; Negri, E.; Dal Maso, L.; Serraino, D.; La Vecchia, C. Dietary intake of selected micronutrients and the risk of pancreatic cancer: An Italian casecontrol study. Ann. Oncol. 2010, 22, 202-206.

95. Wenger, F.A.; Kilian, M.; Ridders, J.; Stahlknecht, P.; Schimke, I.; Guski, H.; Jacobi, C.A.; Müller, J.M. Influence of antioxidative vitamins A, C and E on lipid peroxidation in BOPinduced pancreatic cancer in Syrian hamsters. Prostaglandins Leukot. Essent. Fatty Acids 2001, 65, 165-171.

96. Wolff, R.A. Chemoprevention for pancreatic cancer. Int. J. Gastrointest Cancer 2003, 33, 27-41.

97. Kusama, T.; Mukai, M.; Iwasaki, T.; Tatsuta, M.; Matsumoto, Y.; Akedo, H.; Inoue, M.; Nakamura, H. 3-Hydroxy-3-methylglutaryl-coenzyme a reductase inhibitors reduce human pancreatic cancer cell invasion and metastasis. Gastroenterology 2002, 122, 308-317.

98. Khurana, V.; Sheth, A.; Caldito, G.; Barkin, J.S. Statins reduce the risk of pancreatic cancer in humans: A case-control study of half a million veterans. Pancreas 2007, 34, 260-265.

99. Bonovas, S.; Filioussi, K.; Sitaras, N.M. Statins are not associated with a reduced risk of pancreatic cancer at the population level, when taken at low doses for managing hypercholesterolemia: Evidence from a meta-analysis of 12 studies. Am. J. Gastroenterol. 2008, 103, 2646-2651.

100. Bosetti, C.; La Vecchia, C. Aspirin and cancer risk: A summary review to 2007. Recent Results Cancer Res. 2009, 181, 231-251.

101. Larsson, S.C.; Giovannucci, E.; Bergkvist, L.; Wolk, A. Aspirin and nonsteroidal antiinflammatory drug use and risk of pancreatic cancer: A meta-analysis. Cancer Epidemiol. Biomarkers Prev. 2006, 15, 2561-2564.

102. Bonifazi, M.; Gallus, S.; Bosetti, C.; Polesel, J.; Serraino, D.; Talamini, R.; Negi, E.; La Vecchia, C. Aspirin use and pancreatic cancer risk. Eur. J. Cancer Prev. 2010, 19, 352-354.

103. Anderson, K.E.; Johnson, T.W.; Lazovich, D.; Folsom, A.R. Association between nonsteroidal anti-inflammatory drug use and the incidence of pancreatic cancer. J. Natl. Cancer Inst. 2002, 94, 1168-1171.

104. Schernhammer, E.S.; Kang, J.H.; Chan, A.T.; Michaud, D.S.; Skinner, H.G.; Giovannucci, E.; Colditz, G.A.; Fuchs, C.S. A prospective study of aspirin use and the risk of pancreatic cancer in women. J. Natl. Cancer Inst. 2004, 96, 22-28.

105. Kisfalvi, K.; Eibl, G.; Sinnett-Smith, J.; Rozengurt, E. Metformin disrupts crosstalk between G protein-coupled receptor and insulin receptor signaling systems and inhibits pancreatic cancer growth. Cancer Res. 2009, 69, 6539-6545.

106. Feng, Y.H.; Velazquez-Torres, G.; Gully, C.; Chen, J.; Lee, M.H.; Yeung, S.C. The impact of type 2 diabetes and antidiabetic drugs on cancer cell growth. Cell. Mol. Med. 2010, doi: 10.1111/j.1582-4934.2010.01083.X.

107. Li, D.; Yeung, S.C.; Hassan, M.M.; Konopleva, M.; Abbruzzese, J.L. Antidiabetic therapies affect risk of pancreatic cancer. Gastroenterology 2009, 137, 482-488.

108. Lin, Y.; Tamakoshi, A.; Hayakawa, T.; Naruse, S.; Kitagawa, M.; Ohno, Y. Nutritional factors and risk of pancreatic cancer: A population-based case-control study based on direct interview in Japan. J. Gastroenterol. 2005, 40, 297-301. 
109. Takeuchi, T.; Nakao, M.; Nomura, K.; Yano, E. Association of metabolic syndrome with smoking and alcohol intake in Japanese men. Nicotine Tob. Res. 2009, 11, 1093-1098.

110.Ashakumary, L.; Vijayammal, P.L. Effect of nicotine on lipoprotein metabolism in rats. Lipids 1997, 32, 311-315.

111. Hill, M.J.; Metcalfe, D.; McTernan, P.G. Obesity and diabetes: Lipids, 'nowhere to run to'. Clin. Sci. (Lond) 2009, 116, 113-123.

112.Hillon, P.; Guiu, B.; Vincent, J.; Petit, J.M. Obesity, type 2 diabetes and risk of digestive cancer. Gastroenterol. Clin. Biol. 2010, 34, 529-533.

113. Takeuchi, Y.; Takahashi, M.; Sakano, K.; Mutoh, M.; Niho, N.; Yamamoto, M.; Sato, H.; Sugimura, T.; Wakabayashi, K. Suppression of $N$-nitrosobis(2-oxopropyl)amine-induced pancreatic carcinogenesis in hamsters by pioglitazone, a ligand of peroxisome proliferatoractivated receptor gamma. Carcinogenesis 2007, 28, 1692-1696.

114. Schneider, M.B.; Matsuzaki, H.; Haorah, J.; Ulrich, A.; Standop, J.; Ding, X.Z.; Adrian, T.E.; Pour, P.M. Prevention of pancreatic cancer induction in hamsters by metformin. Gastroenterology 2001, 120, 1263-1270.

115. Staels, B. Metformin and pioglitazone: Effectively treating insulin resistance. Curr. Med. Res. Opin. 2006, 22 (Suppl. 2), S27-S37.

116. Tucker, O.N.; Dannenberg, A.J.; Yang, E.K.; Zhang, F.; Teng, L.; Daly, J.M.; Soslow, R.A.; Masferrer, J.L.; Woerner, B.M.; Koki, A.T.; Fahey, T.J. 3rd. Cyclooxygenase-2 expression is upregulated in human pancreatic cancer. Cancer Res. 1999, 59, 987-990.

117. Molina, M.A.; Sitja-Arnau, M.; Lemoine, M.G.; Frazier, M.L.; Sinicrope, F.A. Increased cyclooxygenase-2 expression in human pancreatic carcinomas and cell lines: Growth inhibition by nonsteroidal anti-inflammatory drugs. Cancer Res. 1999, 59, 4356-4362.

118. Furukawa, F.; Nishikawa, A.; Lee, I.S.; Kanki, K.; Umemura, T.; Okazaki, K.; Kawamori, T.; Wakabayashi, K.; Hirose, M. A cyclooxygenase-2 inhibitor, nimesulide, inhibits postinitiation phase of N-nitrosobis(2-oxopropyl)amine-induced pancreatic carcinogenesis in hamsters. Int. J. Cancer 2003, 104, 269-273.

119. Takahashi, M.; Furukawa, F.; Toyoda, K.; Sato, H.; Hasegawa, R.; Imaida, K.; Hayashi, Y. Effects of various prostaglandin synthesis inhibitors on pancreatic carcinogenesis in hamsters after initiation with N-nitrosobis(2-oxopropyl)amine. Carcinogenesis 1990, 11, 393-395.

120. Nishikawa, A.; Furukawa, F.; Lee, I.S.; Tanaka, T.; Hirose, M. Potent chemopreventive agents against pancreatic cancer. Curr. Cancer Drug Targets 2004, 4, 373-384.

121. Ouyang, N.; Williams, J.L.; Tsioulias, G.J.; Gao, J.; Iatropoulos, M.J.; Kopelovich, L.; Kashfi, K.; Rigas, B. Nitric oxide-donating aspirin prevents pancreatic cancer in a hamster tumor model. Cancer Res. 2006, 66, 4503-4511.

122. Schuller, H.M.; Zhang, L.; Weddle, D.L.; Castonguay, A.; Walker, K.; Miller, M.S. The cyclooxygenase inhibitor ibuprofen and the FLAP inhibitor MK886 inhibit pancreatic carcinogenesis induced in hamsters by transplacental exposure to ethanol and the tobacco carcinogen NNK. J. Cancer Res. Clin. Oncol. 2002, 128, 525-532.

123. Fendrich, V.; Chen, N.M.; Neef, M.; Waldmann, J.; Buchholz, M.; Feldmann, G.; Slater, E.P.; Maitra, A.; Bartsch, D.K. The angiotensin-I-converting enzyme inhibitor enalapril and aspirin 
delay progression of pancreatic intraepithelial neoplasia and cancer formation in a genetically engineered mouse model of pancreatic cancer. Gut 2010, 59, 630-637.

124. Funahashi, H.; Satake, M.; Dawson, D.; Huynh, N.-A.; Reber, H.A.; Hines, O.J.; Eibl, G. Delayed progression of pancreatic intraepithelial neoplasia in a conditional Kras ${ }^{\mathrm{G} 2 \mathrm{D}}$ mouse model by a selective cyclooxygenase-2 inhibitor. Cancer Res. 2007, 67, 7068-7071.

125. Hennig, R.; Ding, X.Z.; Tong, W.G.; Schneider, M.B.; Standop, J.; Friess, H.; Büchler, M.W.; Pour, P.M.; Adrian, T.E. 5-Lipoxygenase and leukotriene B(4) receptor are expressed in human pancreatic cancers but not in pancreatic ducts in normal tissue. Am. J. Pathol. 2002, 161, 421-428.

126. Hennig, R.; Grippo, P.; Ding, X.Z.; Rao, S.M.; Buchler, M.W.; Friess, H.; Talamonti, M.S.; Bell, R.H.; Adrian, T.E. 5-Lipoxygenase, a marker for early pancreatic intraepithelial neoplastic lesions. Cancer Res. 2005, 65, 6011-6016.

127. Wenger, F.A.; Kilian, M.; Bisevac, M.; Khodadayan, C.; von Seebach, M.; Schimke, I.; Guski, H.; Müller, J.M. Effects of Celebrex and Zyflo on liver metastasis and lipidperoxidation in pancreatic cancer in Syrian hamsters. Clin. Exp. Metastasis 2002, 19, 681-687.

128. Vickers, S.M.; MacMillan-Crow, L.A.; Green, M.; Ellis, C.; Thompson, J.A. Association of increased immunostaining for inducible nitric oxide synthase and nitrotyrosine with fibroblast growth factor transformation in pancreatic cancer. Arch. Surg. 1999, 134, 245-251.

129. Kong, G.; Kim, E.K.; Kim, W.S.; Lee, K.T.; Lee, Y.W.; Lee, J.K.; Paik, S.W.; Rhee, J.C. Role of cyclooxygenase-2 and inducible nitric oxide synthase in pancreatic cancer. J. Gastroenterol. Hepatol. 2002, 17, 914-921.

130. Franco, L.; Doria, D.; Bertazzoni, E.; Benini, A.; Bassi, C. Increased expression of inducible nitric oxide synthase and cyclooxygenase-2 in pancreatic cancer. Prostaglandins Other Lipid Mediat. 2004, 73, 51-58.

131.Takahashi, M.; Kitahashi, T.; Ishigamori, R.; Mutoh, M.; Komiya, M.; Sato, H.; Kamanaka, Y.; Naka, M.; Maruyama, T.; Sugimura, T.; Wakabayashi, K. Increased expression of inducible nitric oxide synthase (iNOS) in $N$-nitrosobis(2-oxopropyl)amine-induced hamster pancreatic carcinogenesis and prevention of cancer development by ONO-1714, an iNOS inhibitor. Carcinogenesis 2008, 29, 1608-1613.

132. Takahashi, M.; Mutoh, M.; Shoji, Y.; Kamanaka, Y.; Naka, M.; Maruyama, T.; Sugimura, T.; Wakabayashi, K. Transfection of K-ras ${ }^{\text {Asp12 }}$ cDNA markedly elevates IL-1beta- and lipopolysaccharide-mediated inducible nitric oxide synthase expression in rat intestinal epithelial cells. Oncogene 2003, 22, 7667-7676.

133. Koshiba, T.; Hosotani, R.; Wada, M.; Miyamoto, Y.; Fujimoto, K.; Lee, J.U.; Doi, R.; Arii, S.; Imamura, M. Involvement of matrix metalloproteinase-2 activity in invasion and metastasis of pancreatic carcinoma. Cancer 1998, 82, 642-650.

134. Kilian, M.; Gregor, J.I.; Heukamp, I.; Hanel, M.; Ahlgrimm, M.; Schimke, I.; Kristiansen, G.; Ommer, A.; Walz, M.K.; Jacobi, C.A.; Wenger, F.A. Matrix metalloproteinase inhibitor RO 282653 decreases liver metastasis by reduction of MMP-2 and MMP-9 concentration in BOPinduced ductal pancreatic cancer in Syrian Hamsters: Inhibition of matrix metalloproteinases in pancreatic cancer. Prostaglandins Leukot. Essent. Fatty Acids 2006, 75, 429-434. 
135. Nakamura, H.; Nishikawa, A.; Furukawa, F.; Kasahara, K.; Miyauchi, M.; Son, H.Y.; Hirose, M. Inhibitory effects of protocatechuic acid on the post-initiation phase of hamster pancreatic carcinogenesis induced by $N$-nitrosobis(2-oxopropyl)amine. Anticancer Res. 2000, 20, 3423-3427.

136. Hiura, A.; Tsutsumi, M.; Satake, K. Inhibitory effect of green tea extract on the process of pancreatic carcinogenesis induced by $N$-nitrosobis-(2-oxypropyl)amine (BOP) and on tumor promotion after transplantation of $N$-nitrosobis-(2-hydroxypropyl)amine (BHP)-induced pancreatic cancer in Syrian hamsters. Pancreas 1997, 15, 272-277.

137. Mizumoto, K.; Ito, S.; Kitazawa, S.; Tsutsumi, M.; Denda, A.; Konishi, Y. Inhibitory effect of butylated hydroxyanisole administration on pancreatic carcinogenesis in Syrian hamsters initiated with $N$-nitrosobis(2-oxopropyl)amine. Carcinogenesis 1989, 10, 1491-1494.

138. Yokomatsu, H.; Hiura, A.; Tsutsumi, M.; Satake, K. Inhibitory effect of sarcophytol A on pancreatic carcinogenesis after initiation by $N$-nitrosobis(2-oxypropyl)amine in Syrian hamsters. Pancreas 1996, 13, 154-159.

139. Furukawa, F.; Nishikawa, A.; Lee, I.S.; Son, H.Y.; Nakamura, H.; Miyauchi, M.; Takahashi, M.; Hirose, M. Inhibition by methionine of pancreatic carcinogenesis in hamsters after initiation with $N$-nitrosobis(2-oxopropyl) amine. Cancer Lett. 2000, 152, 163-167.

140. Nishikawa, A.; Furukawa, F.; Uneyama, C.; Ikezaki, S.; Tanakamaru, Z.; Chung, F.L.; Takahashi, M.; Hayashi, Y. Chemopreventive effects of phenethyl isothiocyanate on lung and pancreatic tumorigenesis in $\mathrm{N}$-nitrosobis(2-oxopropyl)amine-treated hamsters. Carcinogenesis 1996, 17, 1381-1384.

141.Nishikawa, A.; Lee, I.S.; Uneyama, C.; Furukawa, F.; Kim, H.C.; Kasahara, K.; Huh, N.; Takahashi, M. Mechanistic insights into chemopreventive effects of phenethyl isothiocyanate in $N$-nitrosobis(2-oxopropyl)amine-treated hamsters. Jpn. J. Cancer Res. 1997, 88, 1137-1142.

142. Nishikawa, A.; Furukawa, F.; Kasahara, K.; Tanakamaru, Z.; Miyauchi, M.; Nakamura, H.; Ikeda, T.; Imazawa, T.; Hirose, M. Failure of phenethyl isothiocyanate to inhibit hamster tumorigenesis induced by N-nitrosobis(2-oxopropyl)amine when given during the post-initiation phase. Cancer Lett. 1999, 141, 109-115.

143. Nishikawa, A.; Furukawa, F.; Ikezaki, S.; Tanakamaru, Z.Y.; Chung, F.L.; Takahashi, M.; Hayashi, Y. Chemopreventive effects of 3-phenylpropyl isothiocyanate on hamster lung tumorigenesis initiated with $N$-nitrosobis(2-oxopropyl)amine. Jpn. J. Cancer Res. 1996, 87, 122-126.

144. Son, H.Y.; Nishikawa, A.; Furukawa, F.; Lee, I.S.; Ikeda, T.; Miyauchi, M.; Nakamura, H.; Hirose, M. Modifying effects of 4-phenylbutyl isothiocyanate on $N$-nitrosobis(2oxopropyl)amine-induced tumorigenesis in hamsters. Cancer Lett. 2000, 160, 141-147.

145. Kuroiwa, Y.; Nishikawa, A.; Kitamura, Y.; Kanki, K.; Ishii, Y.; Umemura, T.; Hirose, M. Protective effects of benzyl isothiocyanate and sulforaphane but not resveratrol against initiation of pancreatic carcinogenesis in hamsters. Cancer Lett. 2006, 241, 275-280.

146. Furukawa, F.; Nishikawa, A.; Chihara, T.; Shimpo, K.; Beppu, H.; Kuzuya, H.; Lee, I.S.; Hirose, M. Chemopreventive effects of Aloe arborescens on N-nitrosobis(2-oxopropyl)amine-induced pancreatic carcinogenesis in hamsters. Cancer Lett. 2002, 178, 117-122.

147. Clapper, M.L.; Wood, M.; Leahy, K.; Lang, D.; Miknyoczki, S.; Ruggeri, B.A. Chemopreventive activity of Oltipraz against $N$-nitrosobis(2-oxopropyl)amine (BOP)-induced ductal pancreatic 
carcinoma development and effects on survival of Syrian golden hamsters. Carcinogenesis 1995, 16, 2159-2165.

148. Askari, M.D.; Tsao, M.S.; Schuller, H.M. The tobacco-specific carcinogen, 4(methylnitrosamino)-1-(3-pyridyl)-1-butanone stimulates proliferation of immortalized human pancreatic duct epithelia through beta-adrenergic transactivation of EGF receptors. J. Cancer Res. Clin. Oncol. 2005, 131, 639-648.

149. Schuller, H.M.; Al-Wadei, H.A. Neurotransmitter receptors as central regulators of pancreatic cancer. Future Oncol. 2010, 6, 221-228.

150. Al-Wadei, H.A.; Al-Wadei, M.H.; Schuller, H.M. Prevention of pancreatic cancer by the betablocker propranolol. Anticancer Drugs. 2009, 20, 477-482.

151. Arafat, H.A.; Gong, Q.; Chipitsyna, G.; Rizvi, A.; Saa, C.T.; Yeo, C.J. Antihypertensives as novel antineoplastics: Angiotensin-I-converting enzyme inhibitors and angiotensin II type 1 receptor blockers in pancreatic ductal adenocarcinoma. J. Am. Coll. Surg. 2007, 204, 996-1005

152. Mohammed, A.; Janakiram, N.B.; Li, Q.; Madka, V.; Ely, M.; Lightfoot, S.; Crawford, H.; Steele, V.E.; Rao, C.V. The epidermal growth factor receptor inhibitor gefitinib prevents the progression of pancreatic lesions to carcinoma in a conditional LSL-Kras ${ }^{\mathrm{G} 12 \mathrm{D} /+}$ transgenic mouse model. Cancer Prev. Res. (Phila) 2010, 3, 1417-1426.

153. Morton, J.P.; Karim, S.A.; Graham, K.; Timpson, P.; Jamieson, N.; Athineos, D.; Doyle, B.; McKay, C.; Heung, M.Y.; Oien, K.A.; Frame, M.C.; Evans, T.R.; Sansom, O.J.; Brunton, V.G. Dasatinib inhibits the development of metastases in a mouse model of pancreatic ductal adenocarcinoma. Gastroenterology 2010, 139, 292-303.

154. Liby, K.T.; Royce, D.B.; Risingsong, R.; Williams, C.R.; Maitra, A.; Hruban, R.H.; Sporn, M.B. Synthetic triterpenoids prolong survival in a transgenic mouse model of pancreatic cancer. Cancer Prev. Res. 2010, 3, 1427-1434.

155. Grippo, P.J.; Tuveson, D.A. Deploying mouse models of pancreatic cancer for chemoprevention studies. Cancer Prev. Res. 2010, 3, 1382-1387.

(C) 2011 by the authors; licensee MDPI, Basel, Switzerland. This article is an open access article distributed under the terms and conditions of the Creative Commons Attribution license (http://creativecommons.org/licenses/by/3.0/). 